\title{
Expression of Vascular Endothelial Growth Factor Messenger RNA and Its Encoded Polypeptide Level in Various Liver Diseases
}

\author{
Mohamed Taha ${ }^{1}$ and Heba Sedrak ${ }^{2}$ \\ ${ }^{1}$ Biochemistry Department, Faculty of Pharmacy, ${ }^{2}$ Department of \\ Internal Medicine, Faculty of Medicine, Cairo University, Cairo, Egypt
}

\begin{abstract}
Vascular endothelial growth factor (VEGF) is the most potent mediator that has been found to be implicated in the development of tumor growth by promoting angiogenesis. The aim of the present study was to detect the gene expression of mRNA of VEGF as well as serum level of its encoded polypeptide in patients with various liver diseases to assess whether they are correlated with different clinical, laboratory and histological parameters of these diseases. Subjects and Methods: forty five patients (33males, 12 females) with various liver diseases including chronic hepatitis $C(n=15)$, liver cirrhosis $(n=15)$ and hepatocellular carcinoma $(n=15)$ and fifteen healthy age-matched controls (9 males, 6 females) were included in the study. Gene expression of VEGF m-RNA was studied in tissue samples of all patients using reverse transcriptase-PCR and its encoded polypeptide level was detected in all subjects using ELISA technique. Results: Gene expression of VEGF m-RNA was significantly higher in HCC group as compared to CHC and LC groups. Meanwhile, there was significant statistical difference in VEGF gene expression between CHC and LC groups. Similar statistical differences were reported in the mean serum level of VEGF polypeptide. VEGF m-RNA expression as well as its serum level were correlated significantly with serum albumin only in cirrhotic patients ( $r=0.612$ and $r$ $=0.577$ respectively). There was a significant positive correlation between the serum VEGF level and platelet count in HCC patients $(r=0.421)$ and negative correlation exists between VEGF levels and platelet count in other patient groups and that correlation was highly significant in patients with chronic hepatitis $(r=-0.646)$. Conclusion: Gene expression of m-RNA of VEGF and its encoded polypeptide level were highly over-expressed in HCC and diminished in LC, so its measurement is highly recommended for early detection of malignant transformation of LC to HCC and makes VEGF one of the most important markers of HCC. Moreover, the HCV was able to activate the expression of VEGF in chronic hepatitis $C$ patients.
\end{abstract}

Key words: HCC, CHC, VEGF and Cirrhosis

\section{INTRODUCTION}

Angiogenesis is the process whereby new blood vessels develop from the preexisting vasculature by migration and proliferation of endothelial cells ${ }^{(\mathbf{1})}$. It takes place physiologically during embryonic development, during the normal growth of tissues and the wound 
healing as well as during the growth, invasion and metastatic spread of malignant neoplasms ${ }^{(2)}$. A variety of humeral agents need to be activated to generate a neovascular blood supply or angiogenesis in the human body.

Vascular endothelial growth factor (VEGF) is one of the most important humeral agents need to be activated to ensure the growth of the vascular endothelium (3). VEGF is a potent mediator that has been found to be implicated in the development of tumor growth by promoting angiogenesis $^{(4)}$. VEGF is a heparinbinding glycoprotein that is secreted as a homodimer of $45 \mathrm{KD}^{(5)}$. There are five different molecular species resulting from alternative splicing of the VEGF gene which, according to their number of amino acids, have been termed VEGF121, VEGF145, VEGF165, VEGF189, and VEGF206 ${ }^{(6)}$. VEGF165 is the predominant isoform secreted by a variety of normal and transformed cells whereas VEGF206 is rarely expressed ${ }^{(7)}$.

The biological effects of VEGF are mediated by at least two tyrosine kinase receptors, kinase domain region (KDR) and fms-like tyrosine kinase 1 (flt-1) which bind VEGF with high affinity ${ }^{(8,9)}$. Both receptors are predominantly expressed in vascular endothelial cells ${ }^{(10)}$. Binding of VEGF to its receptors causes receptor dimeriation and activation of the intrinsic kinase followed by autophosphorylation of the receptor and subsequent signal transduction. There are significant differences with respect to biological relevance between KDR/flk-1 and flt-1. KDR/flk-1 but not flt-1 can mediate the mitogenic and chemotactic effects of VEGF and activate signaling pathways such as the mitogenactivated protein kinases in endothelial cells ${ }^{(11,12)}$.

The aim of the present study is to detect the gene expression of m-RNA of VEGF as well as serum levels of its encoded polypeptide in patients with various liver diseases to assess whether they are correlated with different clinical, laboratory and histological parameters of these diseases.

\section{PATIENTS \& METHODS}

The study included 60 individuals classified into two groups: Forty five patients (33males, 12 females, mean age, 47.6 \pm 6.7 years) with various liver diseases including chronic hepatitis $\mathrm{C}$ $(n=15)$, liver cirrhosis $(n=15)$ and hepatocellular carcinoma $(n=15)$. Fifteen healthy age-matched controls (9 males, 6 females, mean age, 44.3 \pm 5.2 years) were used as a control group. Patients were diagnosed and classified according to clinical, laboratory, and histological findings. All patients were subjected to full clinical examination and laboratory investigations in the form of CBC, liver enzymes (AST, ALT, ALP ), liver function tests (total and direct bilirubin, total plasma proteins and albumin, prothrombin time and concentration.), hepatitis markers (HBsAg, HBsAbs, HBcAbs, HCV Abs) and alpha-fetoprotein level (AFP). Abdominal ultrasonography was done for all patients. Determination of necroinflammatory activity and fibrosis index were done for patients with chronic hepatitis C 
(CHC) according to HAI score ${ }^{(13)}$. Histopathological examination of biopsy specimen obtained from patients with HCC was done to evaluate tumor grade according to Bloom and Richards on (14). Liver biopsies were taken after a written consent from all patients who agreed to be members in the present study. The liver biopsies were immediately immersed in lysis buffer and stored at $-80^{\circ} \mathrm{C}$ until required for RNA extraction and polymerase chain reaction (PCR).Blood samples were taken from all individuals included in the current work. Sera obtained by centrifugation of clotted blood samples and stored at $-80^{\circ} \mathrm{C}$ until assayed.

RNA extraction: Total RNA was extracted from frozen liver biopsies according to the method of Chomczynski and Sacchi ${ }^{(15)}$, using QI amp RNA kit provided by Qiagen Inc, USA. The RNA was quantitated at $260 \mathrm{~nm}$ using UV spectrophotometer.

Reverse transcriptase (RT-PCR) for VEGF: Reverse transcription (RT) of RNA was performed for detecting human VEGF using $2 \mu \mathrm{g}$ of total RNA, $1 \mu \mathrm{L}$ (20 pmol) oligo (dT)18 primer and $0.8 \mu \mathrm{L}$ RNA reverse transcriptase for 60 minutes at $37^{\circ} \mathrm{C}$. Each RT product was amplified by polymerase chain reaction (PCR). For amplification of VEGF a sense primer (5'-

ATGGCAGAAGGAGGGCAGCAT-

3') and an antisense primer (5'TTGGTGAGGTTTGATCCGCATCA

T-3') were generated.

cDNAs were amplified by incubation of $4 \mu \mathrm{L}$ of $\mathrm{RT}$ product with $30.5 \mu \mathrm{L}$ water, $4 \mu \mathrm{L} 25 \mathrm{mmol} / \mathrm{L} \mathrm{MgCl}_{2}$, $1 \mu \mathrm{L}$ dNTP's $(10 \mathrm{mM}), 5 \mu \mathrm{L}$ 10x PCR buffer, $\quad 0.5 \mu \mathrm{L} \quad(2.5 \mathrm{U}) \quad$ Taq-DNA-
Polymerase and $2.5 \mu \mathrm{L}$ of each primer. Amplification conditions for 40 cycles were as follows: denaturation at $95^{\circ} \mathrm{C}$ for one minute, annealing at $55^{\circ} \mathrm{C}$ for one minute and extension at $72^{\circ} \mathrm{C}$ for two minutes.

Each PCR reaction product $(10 \mu \mathrm{L})$ was run on a $1.5 \%$ agarose gel and visualized using ethidium bromide. The PCR product yielded a 255bp fragment. Densitometric analysis of PCR products was performed for semiquantitation of the amplified PCR products by using of a densitometer (Molecular Dynamics, Sunnyvale, CA, U.S.A.).The relative amount of VEGF DNA reflected the original amount of the m-RNA.

Measurement of VEGF by using ACCUCYTE Human VEGF kit:

ACCUCYTE Human VEGF is a competitive enzyme immunoassay (EIA), which measures the natural and recombinant forms of the cytokine Vascular Endothelial Growth Factor (VEGF). The kit was provided by Cytimmune Sciences Inc, USA. The amount of VEGF detected in each sample was compared to a VEGF standard curve which demonstrated an inverse relationship between Optical Density (O.D.) and cytokine concentration.

Statistical Analysis: Data are expressed as mean \pm S.D. Statistical analysis of the obtained results was performed by using independent t-test to compare between two groups at $\mathrm{p}<0.05$. One Way ANOVA was used to compare between more than two groups followed by Duncan multiple comparison test at $\mathrm{p}<0.05$. Correlation between VEGFand various parameters were evaluated using Pearson correlation coefficient (r) at $\mathrm{p}<0.05$. 


\section{RESULTS}

Results of the present study are shown in tables 1-8 and illustrated in figure 1 .

Table (1): Demographic and laboratory data of all patients groups (Mean \pm S.D.).

\begin{tabular}{|l|l|l|l|l|l|}
\hline \multicolumn{1}{|c|}{ Variable } & \multicolumn{1}{|c|}{$\begin{array}{c}\text { LC } \\
(\mathbf{n}=\mathbf{1 5})\end{array}$} & \multicolumn{1}{c|}{$\begin{array}{c}\text { CHC } \\
(\mathbf{n}=\mathbf{1 5})\end{array}$} & \multicolumn{1}{c|}{$\begin{array}{c}\text { HCC } \\
(\mathbf{n = 1 5})\end{array}$} & \multicolumn{1}{|c|}{ F-value } & p-value \\
\hline Gender (M/F) & $12 / 3$ & $8 / 7$ & $13 / 2$ & - & - \\
\hline Age (Years & $49.5 \pm 8.4$ & $39.1 \pm 7.3$ & $55.6 \pm 4.4$ & 3.62 & 0.07 \\
\hline ALT (U/L) & $66.0 \pm 39.0$ & $125.7 \pm 60.1$ & $48.9 \pm 22.4$ & 487.37 & $0.000^{*}$ \\
\hline AST (U/L) & $97.7 \pm 55.9$ & $139.5 \pm 75.4$ & $76.9 \pm 27.7$ & 304.32 & $0.000^{*}$ \\
\hline PC (\%) & $50.2 \pm 15.4$ & $70.3 \pm 11.6$ & $58.5 \pm 9.3$ & 306.07 & $0.000^{*}$ \\
\hline Albumin (g/dl3.) & $2.7 \pm 0.7$ & $4.0 \pm 0.1$ & $3.1 \pm 0.5$ & 133.00 & $0.000^{*}$ \\
\hline $\begin{array}{l}\text { Platelet Count } \\
\text { (x1000/cm) }\end{array}$ & $108.7 \mathrm{a} \pm 40.8$ & $208.5 \mathrm{c} \pm 69.1$ & $137.3 \mathrm{~b} \pm 56.1$ & 923.00 & $0.000^{*}$ \\
\hline AFP (nag/ml.) & $114.3 \pm 10.3$ & $32.0 \pm 12.0$ & $2163.0 \pm 875.0$ & 1963.91 & $0.000^{*}$ \\
\hline
\end{tabular}

* Statistically significant difference at $p<0.001$.

Table (2): VEGF levels according to histopathological classification of studied CHC patients (Mean \pm S.D.).

\begin{tabular}{|c|c|c|c|c|c|}
\hline Variable & $\begin{array}{c}\text { No fibrosis } \\
(\mathbf{n = 5})\end{array}$ & $\begin{array}{c}\text { Stage 1 } \\
(\mathbf{n = 2})\end{array}$ & $\begin{array}{c}\text { Stage 2 } \\
(\mathbf{n = 3})\end{array}$ & $\begin{array}{c}\text { Stage 3 } \\
(\mathbf{n}=\mathbf{5})\end{array}$ & \multicolumn{1}{c|}{$\begin{array}{c}\text { p- } \\
\text { value }\end{array}$} \\
\hline $\begin{array}{c}\text { VEGF m-RNA } \\
(\mu \mathrm{g} / \mathrm{ml} .)\end{array}$ & $301.2 \pm 153.5$ & $392.6 \pm 145.3$ & $314.3 \pm 122.2$ & $370.6 \pm 244.7$ & $\begin{array}{l}>0.05 \\
\mathrm{NS}\end{array}$ \\
\hline $\begin{array}{c}\text { Serum VEGF } \\
(\mathrm{Pg} / \mathrm{ml} .)\end{array}$ & $1688.4 \pm 725.8$ & $1813.5 \pm 958.4$ & $1697.5 \pm 904.7$ & $1878.4 \pm 709.3$ & $\begin{array}{l}>0.05 \\
\mathrm{NS}\end{array}$ \\
\hline
\end{tabular}

NS: non significant 
Table (3): VEGF levels according to tumor grade in studied HCC cases (Mean \pm S.D.).

\begin{tabular}{|c|c|c|l|}
\hline Variable & \multicolumn{1}{|c|}{$\begin{array}{c}\text { Grade I } \\
(\mathrm{n}=4)\end{array}$} & $\begin{array}{c}\text { Grade II } \\
(\mathrm{n}=11)\end{array}$ & p- value \\
\hline $\begin{array}{c}\text { VEGF m-RNA } \\
(\mu \mathrm{g} / \mathrm{ml} .)\end{array}$ & $2324.4 \pm 915.3$ & $2115.7 \pm 1124.6$ & $\begin{array}{l}>0.05 \\
\text { NS }\end{array}$ \\
\hline $\begin{array}{c}\text { Serum VEGF } \\
(\mathrm{Pg} / \mathrm{ml} .)\end{array}$ & $2190.2 \pm 1530.8$ & $2110.6 \pm 1034.7$ & $\begin{array}{l}>0.05 \\
\text { NS }\end{array}$ \\
\hline
\end{tabular}

NS: non significant

Table (4): Tissue concentration of the PCR products ( $\mu \mathrm{g} / \mathrm{ml}$.) in all subgroups of patients (Mean \pm S.D.).

\begin{tabular}{|c|c|c|}
\hline $\begin{array}{c}\text { LC group } \\
(\mathbf{n}=\mathbf{1 5})\end{array}$ & $\begin{array}{c}\text { CHC group } \\
(\mathbf{n}=\mathbf{1 5})\end{array}$ & $\begin{array}{c}\text { HCC group } \\
(\mathbf{n}=\mathbf{1 5})\end{array}$ \\
\hline $185.6 \pm 77.2$ & $384.3 \pm 179.5^{*}$ & $2243.3 \pm 965.8^{* *}$ \\
\hline
\end{tabular}

* Statistically significant versus LC and HCC at $\mathrm{p}<0.01$.

** Statistically significant versus LC and CHC at $\mathrm{p}<0.001$.

Table (5): Serum level of VEGF (Pg/ml.) in studied patient groups in relation to control group (Mean \pm S.D.).

\begin{tabular}{|l|l|l|l|}
\hline $\begin{array}{c}\text { Control group } \\
(\mathbf{n}=\mathbf{1 5})\end{array}$ & $\begin{array}{c}\text { LC group } \\
(\mathbf{n}=\mathbf{1 5})\end{array}$ & $\begin{array}{c}\text { CHC group } \\
(\mathbf{n}=\mathbf{1 5})\end{array}$ & $\begin{array}{c}\text { HCC group } \\
(\mathbf{n}=\mathbf{1 5})\end{array}$ \\
\hline $302.7 \pm 92.6$ & $1042.0 \pm 504.2^{*}$ & $1887.3 \pm 870.9^{*}$ & $2488.7 \pm 1556.7^{*}$ \\
\hline
\end{tabular}

* Statistically significant versus control at $p<0.01$

Table (6): Correlation between VEGF levels \& different studied parameters in HCC patients.

\begin{tabular}{|l|l|l|l|l|}
\hline \multirow{2}{*}{ Variables } & \multicolumn{2}{|c|}{$\begin{array}{c}\text { VEGF m-RNA } \\
(\boldsymbol{\mu g} / \mathbf{m l} \mathbf{)}\end{array}$} & \multicolumn{2}{c|}{$\begin{array}{c}\text { Serum VEGF } \\
(\mathbf{P g} / \mathbf{m l})\end{array}$} \\
\cline { 2 - 5 } & $\mathbf{R}$ & $\mathbf{P}$ & $\mathbf{r}$ & $\mathbf{P}$ \\
\hline Albumin (g/dl.) & 0.132 & $>0.05$ & 0.162 & $>0.05$ \\
\hline Platelet count (x1000/cm) & 0.211 & $>0.05$ & 0.421 & $<0.05$ \\
\hline AFP (ng/ml.) & 0.117 & $>0.05$ & 0.146 & $>0.05$ \\
\hline
\end{tabular}


Table (7): Correlation between VEGF levels \& different studied parameters in CHC patients.

\begin{tabular}{|l|l|l|l|l|}
\hline \multirow{2}{*}{ Variables } & \multicolumn{2}{|c|}{$\begin{array}{c}\text { VEGF m-RNA } \\
(\mu \mathrm{g} / \mathrm{ml})\end{array}$} & \multicolumn{2}{c|}{$\begin{array}{c}\text { Serum VEGF } \\
(\mathrm{Pg} / \mathrm{ml})\end{array}$} \\
\cline { 2 - 5 } & $\mathrm{R}$ & $\mathrm{P}$ & $\mathrm{r}$ & $\mathrm{P}$ \\
\hline Albumin (g/dl.) & 0.098 & $>0.05$ & 0.122 & $>0.05$ \\
\hline Platelet count (x1000/cm) & -0.531 & $<0.05$ & -0.646 & $<0.05$ \\
\hline AFP (nag./ml..) & 0.041 & $>0.05$ & 0.063 & $>0.05$ \\
\hline
\end{tabular}

Table (8): Correlation between VEGF levels and different studied parameters in LC patients.

\begin{tabular}{|l|l|l|l|l|}
\hline \multirow{2}{*}{ Variables } & \multicolumn{2}{|c|}{$\begin{array}{c}\text { VEGF m-RNA } \\
(\mu \mathrm{g} / \mathrm{mL})\end{array}$} & \multicolumn{2}{c|}{$\begin{array}{c}\text { Serum VEGF } \\
(\mathrm{Pg} / \mathrm{mL})\end{array}$} \\
\cline { 2 - 5 } & $\mathrm{r}$ & $\mathrm{p}$ & $\mathrm{r}$ & $\mathrm{P}$ \\
\hline Albumin $(\mathrm{g} / \mathrm{dL})$ & 0.612 & $<0.05$ & 0.577 & $<0.05$ \\
\hline Platelet count $(\mathrm{x} 1000 / \mathrm{cm})$ & -0.214 & $>0.05$ & -0.223 & $>0.05$ \\
\hline AFP $(\mathrm{ng} / \mathrm{mL})$ & 0.104 & $>0.05$ & 0.083 & $>0.05$ \\
\hline
\end{tabular}

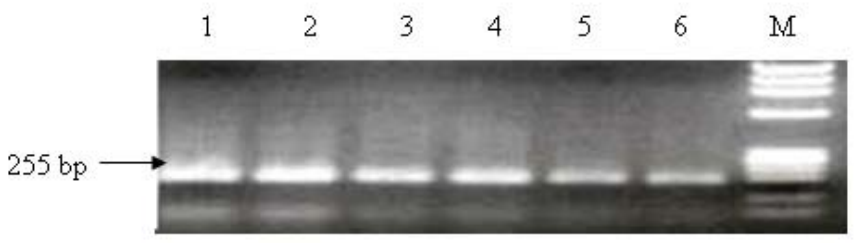

Fig (1): Agarose gel electrophoresis stained with ethidium bromide showing positive bands at $255 \mathrm{bp}$ for gene expression of VEGF.

M: Molecular DNA Marker.

Lanes 1,2: HCC cases.

Lanes 3,4: Chronic hepatitis cases.

Lanes 5,6: Cirrhosis cases.

As shown in Table (4), (Figure 1) gene expression of m-RNA of VEGF was significantly higher in HCC group (2243.3 \pm 965.8$)$ as compared to CHC (384.3 \pm 179.5$)$ and
LC (185.6 \pm 77.2$)$ groups $\quad(\mathrm{P}<0.001)$. Meanwhile, there was significant statistical difference in VEGF gene expression between $\mathrm{CHC}$ and LC groups $(\mathrm{P}<0.01)$. The mean serum 
VEGF values in CHC, LC, HCC groups were $\quad(1887.3 \pm 870.9)$, (1042.0 \pm 504.2$)$, and $(2488.7 \pm 1556.7)$ respectively, and all were significantly higher than control group (302.7 \pm 92.6$)$, and the difference between groups was statistically significant at $\mathrm{P}<0.01$ (Table 5).

VEGF m-RNA expression as well as its serum level were correlated significantly with serum albumin only in cirrhotic patients $(r=0.612$ and $r=$ 0.577 respectively). There was a significant positive correlation between the serum VEGF level and platelet count in HCC patients ( $\mathrm{r}=$ 0.421 ) and negative correlation was observed between VEGF levels and platelet count in other patient groups and this correlation was highly significant in patients with chronic hepatitis $(r=-0.646)$. Among patients with HCC no significant difference was noted between VEGF levels and grades of tumor $(P>0.05)$, and, also, no significant correlation was observed between VEGF m-RNA expression as well as its serum level and AFP ( $r=0.117$ and $r=0.146$ respectively). In group of chronic hepatitis $\mathrm{C}$ no significant difference was found between VEGF and degrees of fibrosis $(\mathrm{P}>0.05)$.

\section{DISCUSSION}

Hepatocellular carcinoma (HCC) is the third largest cause of cancerrelated death behind only lung and colon cancers. HCC is a highly vascular tumor that expresses VEGF (16)

VEGF is known to play an important role not only in the angiogenesis of different human tumors but, also, in physiological and non-malignant pathological conditions ${ }^{17)}$.In addition, increasing evidence indicates that hypoxia and VEGFinduced angiogenesis may, also, contribute to wound healing and tissue repair ${ }^{\mathbf{( 1 8 )}}$. It has been shown that the VEGF level in serum is of value for predicting disease progression and prognosis in different cancers, such as the gastrointestinal, breast, lung, urothelium, ovary, and lymphoma ${ }^{(19)}$.

Expression of VEGF m-RNA in serum might not always correlate significantly with the gene expression level in tumor tissues (20), therefore; liver tissue was used for measurement of VEGF m-RNA instead of serum in the present study. However, compared with expression in tumor tissue, the advantage of measurement of serum VEGF level is that it can be performed without tissue specimens and repeated (21). According to Jeng et al. ${ }^{(19)}$ for more accuracy; we chose to measure m-RNA expression of VEGF in liver tissue in addition to its encoded polypeptide level in serum.

In the present study, there was a statistically significant over-expression of VEGF m-RNA in patients with hepatocellular carcinoma as compared to patients with chronic hepatitis and patients with liver cirrhosis that showed minimal VEGF m-RNA expression. Patients with HCC showed the highest elevation in VEGF levels $(\mathrm{p}<0.001)$.

These findings are in agreement with those of Poon et al. (22) and Iavarone et al. ${ }^{(4)}$ who found that the VEGF concentration was elevated in patients with HCC and could be a new marker predicting angiogenesis, invasion, metastasis and prognosis of 
HCC. In addition to its known angiogenic properties, VEGF may promote HCC spreading into normal liver parenchyma ${ }^{(23)}$.

The results of the current study are highly supported by the findings of Brodsky et al. ${ }^{(24)}$ who reported that one of the major stimuli for angiogenesis in these liver diseases could be VEGF as the VEGF expression was higher in HCC and diminished in cirrhotic nodules, thus strongly correlating with the degree of vascularization.

The exact mechanism of increased VEGF in HCC is not clear but the production of VEGF by HCC cells could be explained on the basis that regions of low oxygen (hypoxia) and necrosis are common features of solid tumors and a marked elevation in VEGF expression in tumor cells around necrotic areas has been suggested in some neoplasms (25). Therefore, hypoxia may play a central role in VEGF upregulation in HCC ${ }^{(6)}$. Several lines of evidence indicate that enhanced VEGF expression in response to hypoxia is due to transcriptional activation ${ }^{(26)}$ as well as m-RNA stabilization ${ }^{(27)}$. In addition, an internal ribosome entry site ensures efficient translation of VEGF m-RNA, even under hypoxic conditions ${ }^{(\mathbf{2 8})}$.

The current study showed that patients with liver cirrhosis elicited a significant reduction of tissue VEGF as compared to $\mathrm{CHC}$ patients $(\mathrm{p}<0.01)$. VEGF expression in liver cirrhosis has been suggested to result from proinflammatory cytokines released by infiltrating lymphocytes. That hypothesis is supported by in vitro studies showing that tumor necrosis factor $\alpha$ and interleukin $\beta$ can increase VEGF secretion (29). Furthermore, VEGF expression is known to be induced by insulin-like growth factor II ${ }^{(30)}$ which is highly expressed in cirrhotic liver and HCC tissues ${ }^{(31)}$.

In the present study there was a significant elevation in circulating VEGF levels in patients with chronic hepatitis than in the control group .This observation is in agreement with that of Jinno et al.. ${ }^{(32)}$ and Makhlouf et al. (33) who found a significant increase in circulating VEGF levels in chronic hepatitis patients compared to healthy controls. This may be attributed to hepatic angiogenesis occurring in presence of chronic hepatitis C infection ${ }^{(34)}$.

Although patients of liver cirrhosis showed the least elevation of serum VEGF among the studied groups, yet it was significantly higher than controls. That finding coincides with results of Jinno et al. $^{(32)}$ and Makhlouf et al. ${ }^{(33)}$ and differs from that of Akiyoshi et al. ${ }^{(35)}$ and Genesca et al. ${ }^{(36)}$ who reported that circulating VEGF levels were significantly lower in patients with liver cirrhosis than in controls. Levy et al. ${ }^{(37)}$ and El Assal et al. ${ }^{(38)}$ found elevated levels of serum VEGF in cirrhotic patients. They attributed this to sustained mechanically reduced blood flow which leads to hepatocyte hypoxia and upregulation of VEGF.

In spite of marked elevation of gene expression of VEGF in HCC patients, there was no correlation between its level and tumor grade. That result agrees with that of Hideaki et al. ${ }^{(39)}$, El Assal et al. ${ }^{(38)}$ and Jeng et al. ${ }^{(19)}$ who found no correlation between VEGF expression and tumor 
grade, while Tormiura et al. ${ }^{(40)}$ reported a weak positive correlation between tumor grade and VEGF expression. On the opposite side, Yamaguchi et al. ${ }^{(29)}$ found that VEGF expression was negatively correlated with tumor grade.

In the present study there was no correlation between VEGF levels and histological activity index in chronic hepatitis patients. These findings resemble those of Akiyoshi et al. ${ }^{(35)}$ who reported absent correlation between serum VEGF levels, necroinflammatory score and fibrosis score.

A positive correlation was found between the serum VEGF level and the platelet count in HCC patients. This result is in accordance with findings reported by other authors ${ }^{(32}$, 41) .Several studies have shown that platelets have the function of storing circulating VEGF ${ }^{(42)}$. These studies have, also, shown that the storage and release of VEGF by circulating platelets may have an important role in processes involving platelet and endothelial cell interactions, such as wound healing and tumor invasion. It has been postulated that platelets adhering to circulating tumor cells may be activated to release VEGF at points of adhesion to endothelium, leading to hyperpermeability and extravasation of tumor cells ${ }^{(21)}$.There is ,also, preliminary evidence suggesting that fast-growing tumors may release thrombopoietic cytokines in addition to angiogenic factors such as VEGF. An increase in the number of circulating platelets, by uptake of free VEGF, may focus the effect of that angiogenic factor to sites where activation of platelet takes place, for example, a wound or a tumor (42)
.While others found low serum VEGF level in liver cirrhosis, they attributed this to low platelet count found in cirrhotic patients ${ }^{(35,36)}$.

A significant correlation was found between serum albumin and VEGF levels only in cirrhotic patients. These findings disagreed with those of Assy et al. ${ }^{(43)}$ who reported that VEGF levels reflect neither hepatic synthetic function nor inflammatory activity and suggested that serum VEGF is not the result of damaged hepatocytes but rather a high regenerative capacity.

Conclusion: Gene expression of $\mathrm{m}$ RNA of VEGF and its encoded polypeptide level were highly overexpressed in HCC and diminished in LC, so its measurement is highly recommended for early detection of malignant transformation of LC to HCC and makes VEGF one of the most important markers of HCC. Moreover, the HCV was able to activate the expression of VEGF in chronic hepatitis $\mathrm{C}$ patients.

\section{REFERENCES}

1. Kanematsu M., Osada S., Amaoka N., Goshima S., Kondo H., Nishibori $H$, Kato $H$, Matsuo M., Yokoyama R., Hoshi H. and Moriyama N., (2004): Expression of vascular endothelial growth factor in hepatocellular carcinoma and the surrounding liver: Correlation with angiographically assisted CT. AJR., 183:1585-1593.

2. Folkman J. (1971): Tumor angiogenesis therapeutic implications. N. Engl. J. Med., 285: $1182-1186$. 
3. Ferrara N. (1999): Vascular endothelial growth factor: molecular and biological aspects. Curr.Top. Microbiol. Immunol., 237: 1-30.

4. Iavarone M., Lampertico P., Iannuzzi F., Manenti E, Donato M. F., Arosio E, Bertolini F., Primignani M., Sangiovanni A. and Colombo M. (2007): Increased expression of vascular endothelial growth factor in small hepatocellular carcinoma. J. Viral Hepat., 14(2):133-139.

5. Houck KA, Leung DW, Rowland AM, Winer $J$ and Ferrara N. (1992): Dual regulation of vascular endothelial growth factor bioavailability by genetic and proteolytic mechanisms. J. Biol. Chem., 267: 26031 -26037.

6. Marschall Z., Cramer T., Höcker M., Finkenzeller G., Wiedenmann B.and Rosewicz $S$. (2001): Dual mechanism of vascular endothelial growth factor up-regulation by hypoxia in human hepatocellular carcinoma, Gut 48: 87-96.

7. Houck K.A., Ferrara N. and Winer J., (1991): The vascular endothelial growth factor family: identification of a fourth molecular species and characterization of alternative splicing of RNA. Mol. Endocrinol., 5: 1806-1814.

8. DeVaries C., Escobedo J.A. and Ueno H. (1992): The fms-like tyrosine kinase, a receptor for vascular endothelial growth factor. Science 255: 989-991.

9. Terman BI., DougherVermazen MD. and Carrion
ME (1992): Identification of the KDR tyrosine kinase as a receptor for vascular endothelial cell growth factor. Biochem. Biophys. Res. Commun., 187: 1579-1586.

10. Quinn T., Peters KG. and deVries C. (1993): Fetal liver kinase 1 is a receptor for vascular endothelial growth factor and is selectively expressed in vascular endothelium. Proc. Natl. Acad. Sci. USA, 90: 7533-7537.

11. Millauer B., Wizigmann-Voos S and Schnurch $H$, (1993): High affinity VEGF binding and developmental expression suggest Flk-1 as a major regulator of vasculogenesis and angiogenesis. Cell 72: 835-846.

12. Waltenberger J., ClaessonWelsh L. and Siegbahn A. (1994): Different signal transduction properties of KDR and Flt-1, two receptors for vascular endothelial growth factor. J. Biol. Chem., 269: 26988-26995

13. Knodell RG., Ishak KG. and Brack WC. (1981): Formulation and application of a numerical scoring system for assessing histological activity in asymptomatic chronic active hepatitis : Hepatol. , 51(5): 43l-5

14. Bloom $\mathbf{H}$. and Richardson $W$. (1957): Histologic grading and prognosis in breast cancer.Br. J. Cancer 11:359.

15. Chomczynski P., and Sacchi N. (1987): Single-step method of RNA isolation by acid guanidinium thiocyanate-phenolchloroform extraction. Anal. Biochem., 162: 156-163. 
16. Liovet JM., and Bruix J. (2009): Testing molecular therapies in hepatocellular carcinoma: The need for randomized phase II trials. J. Clin. Oncol., 27(6): 833835.

17. Ferrara N. and Davis-Smyth T. (1997): The biology of vascular endothelial growth factor. Endoc. Rev., 18:4-25.

18. Schied A., Wegner R. and Christina H. (2000): Hypoxia regulated gene expression in fetal wound regeneration and adult wound repair. Pediatric Surg. Int., 16:232-236.

19. Jeng KS., Sheen IS., Wang YC., Gu SL., Chu CM., Shih SC., Wang PC., Chang WH. and Wang HY. (2004): Is the vascular endothelial growth factor messenger RNA expression in resectable hepatocellular carcinoma of prognostic value after resection. World J. Gastroenterol., 5: 676-681.

20. Tokunaga T., Oshika Y., Abe Y, Ozeki Y., Sadehiro S., Kijima H., Tsuchida T., Yamazaki H., Ueyama Y., Tamaoki N. and Nakamura M. (1998): Vascular endothelial growth factor (VEGF) mRNA isoform expression pattern is correlated with liver metastasis and poor prognosis in colon cancer. Br. J. Cancer 77: 9981002.

21. Banks RE, Forbes MA., Kinsey SE, Stanley A., Ingham E, Walters C. and Selby PJ. (1998): Release of the angiogenic cytokine vascular endothelial growth factor (VEGF) from platelets: bearing human hepatocellular carcinoma. Br. J. Cancer 77: 956-964.

22. Poon R.T, Nq I.O., Lau C.P., Zhu L.X., Yu W.C., Lo C.M., Fan S.T. and Wong J. (2001): Serum vascular endothelial growth factor predicts venous invasion in hepatocellular carcinoma. Ann. Surg., 233(2):227-235.

23. Schmitt, M., Horbach, A., Kubitz, R., Frilling, A., and Haussinger, D. (2004): Disruption of hepatocellular tight junctions by vascular endothelial growth factor (VEGF):a novel mechanism for tumor invasion. J. Hepatol., 41: 274-383.

24. Brodsky S.V., Mendelev N., Melamed $M$. and Ramaswamy G. (2007): Vascular density and VEGF expression in hepatic lesions. J. Gastrointest. Liver Dis., 16: 373-377.

25. Brown LF, Berse $B$. and Jackman RW. (1993): Expression of vascular permeability factor (vascular endothelial growth factor) and its receptors in adenocarcinomas of the gastrointestinal tract. Cancer Res., 53: 4727-4735.

26. Forsythe JA., Jiang BH. and Iyer NV.(1996): Activation of vascular endothelial growth factor gene transcription by hypoxiainducible factor 1. Mol. Cell Biol., 16: 4604-4613.

27. Levy NS., Chung S and Furneaux H. (1998): Hypoxic stabilization of vascular endothelial growth factor mRNA by the RNA-binding protein HuR. J. Biol. Chem., 273: 6417-6423. 
28. Stein I., Itin A. and Einat $\mathbf{P}$. (1998): Translation of vascular endothelial growth factor mRNA by internal ribosome entry: implication for translation under hypoxia. Mol. Cell Biol., 18: 3112-3119.

29. Yamaguchi R.,Yano $H$. and Iemura A. (1998): Expression of vascular endothelial growth factor in human hepatocellular carcinoma. Hepatology 28 68-77.

30. Kim KW., Bae SK. and Lee OH. (1998): Insulin-like growth factor II induced by hypoxia may contribute to angiogenesis of human HCC. Cancer Res., 58(2):348-51

31. Park BC., Huh MH. and Seo JH. (1995): Differential expression of transforming growth factor alpha and insulin-like growth factor II in chronic active hepatitis B, cirrhosis and hepatocellular carcinoma. J. Hepatol., 22: 286-294.

32. Jinno $K$, Tanimizu $M$. and Hyodo I. (1998): Circulating vascular endothelial growth factor (VEGF) is a possible tumor marker for metastasis in human hepatocellular carcinoma. J. Gastroenterol., 33: 376-382.

33. Makhlouf M., Aaad A., Zakhari M. (2002): Vascular endothelial growth factor level in chronic liver diseases. J. Egypt. Soc. Parasitol., 32(3):907-921.

34. Mazzanti R.,Messereni L. and Monacchi L. (1997): Chronic viral hepatitis induced by hepatitis $C$ but not hepatitis $B$ virus infection correlate with increased liver angiogenesis. Hepatol., 25:229-234.

35. Akiyoshi F., Sata M. and Suzuki H. (1998): Serum vascular endothelial growth factor levels in various liver diseases. Dig. Dis. Sci., 43:41-45.

36. Genesca J., Mujal A. and Cereto F. (1999): Vascular endothelial growth factor levels in liver cirrhosis. Dig. Dis. Sci., 44:1261-1262.

37. Levy AP., Levy NS. and Goldberg MA. (1996): Posttranscriptional regulation of vascular endothelial growth factor by hypoxia. J. Biol. Chem., 271: 2746-2753.

38. El Assal ON., Yamanoi A., Soda Y., Yamaguchi M., Igarashi M., Yamamoto A., Nabika T. and Nagasue N. (1998): Clinical significance of microvessel density and vascular endothelial growth factor expression in hepatocellular carcinoma and surrounding liver: possible involvement of vascular endothelial growth factor in the angiogenesis of cirrhotic liver. Hepatology 27: 1554-1562.

39. Hideaki M., Jora $\mathbf{M}$. and Masahika A. (1997): Increased expression of vascular endothelial growth factor in human hepatocellular carcinoma. J. Hepatol., 27(5):854-861.

40. Tormiura T., Sata $M$. and Ueno T. (1998): Increased expression of vascular endothelial growth factor is associated with tumor progression in hepatocellular carcinoma. Human Pathol., 29: 986-991. 
41. Poon R.T., Lau C.P., Cheung S.T.,Yu W.C. and Fan S.T.(2003): Quantitative correlation of serum levels and tumor expression of vascular endothelial growth factor in patients with hepatocellular carcinoma. Cancer Res., 63: 31213126.

42. Salgado R., Vermeulen PB. and Benoy I., (1999): Platelet number and interleukin-6 correlate with VEGF but not with bFGF serum levels of advanced cancer patients. Br. J. Cancer 80: 892897.

43. Assy N.; Spira G. and Paizi M. (1999): Effect of vascular endothelial growth factor on hepatic regeneration activity following partial hepatectomy in rats. J. Hepatol., 30: 911-915. 


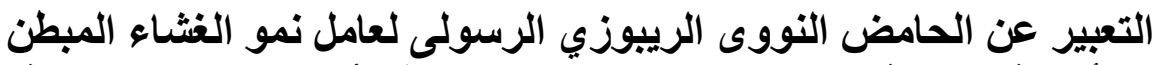

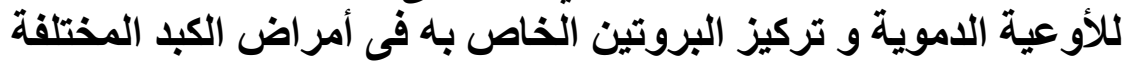

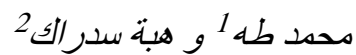

قسما الكيمياء الحيوية1 ـ كلية الصيدلة ، الباطنة العامة2 ـ ـلية الطب ـلية ـ جامعة القاهرة.

ينشط الجهاز الو عائي ليكون شعير ات دموية جديدة أثناء حدوث الأورام وهذه العملية حيوية لنمو و إنتشار الورم الوباء

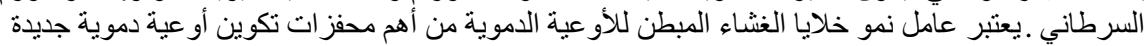

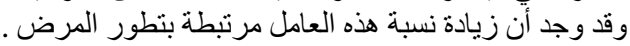

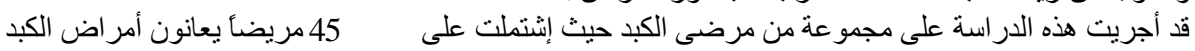

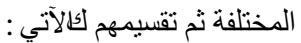

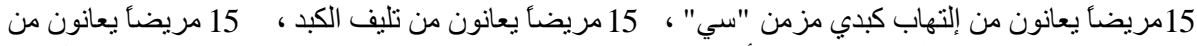

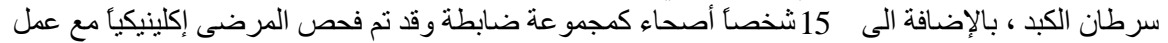

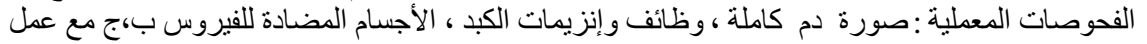

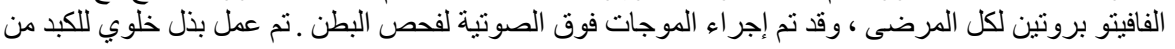

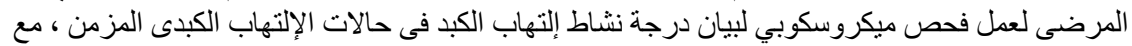

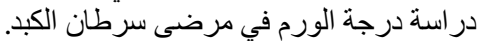

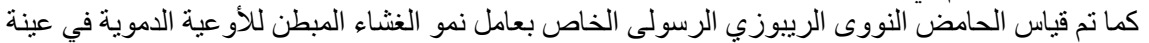

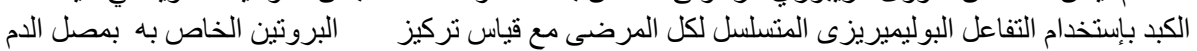

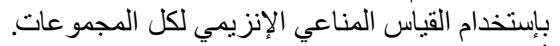

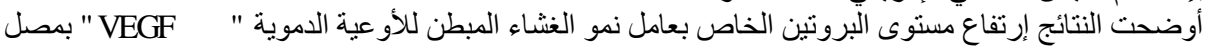

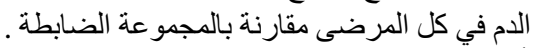

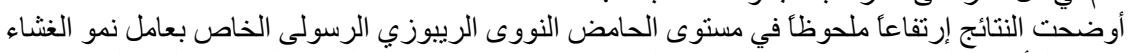

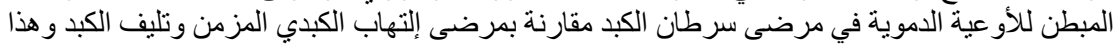

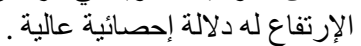

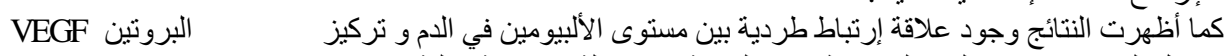

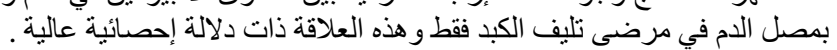

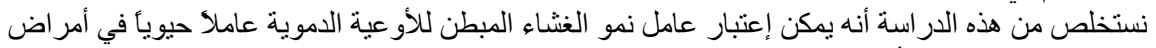

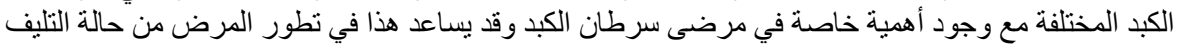

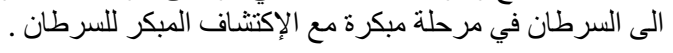

